\title{
MOLECULAR CHARACTERIZATION OF DENGUE VIRUSES TYPE 1 AND 2 ISOLATED FROM A CONCURRENT HUMAN INFECTION
}

Cecília Luiza Simões dos SANTOS(1), Mariana Aparecida Antunes BASTOS(1), Maria Anice Mureb SALLUM(2) \& Iray Maria ROCCO(1)

\begin{abstract}
SUMMARY
In 2001, an autochthonous case of dual viremia, resulting from naturally acquired dengue virus DEN-1 and DEN-2 infections was detected during the dengue outbreak that occurred in Barretos, a city with about 105,000 inhabitants in the North region of São Paulo State. Serotype identification was based on virus isolation to $\mathrm{C} 6 / 36$ mosquito cells culture and immunofluorescence assays using type-specific monoclonal antibodies. The double infection was also confirmed by reverse transcriptase polymerase chain reaction (RT-PCR). Comparative analysis of the 240-nucleotide sequences of E/NS1 gene junction region between the genome of DEN-1 and DEN-2 isolates of the corresponding reference Nauru and PR 159S1 strains, respectively, showed some nucleotide differences, mainly silent mutations in the third codon position. Results of maximum likelihood phylogenetic analysis of E/NS1 gene sequences indicated that both genotypes of DEN-1 and DEN-2 viruses recovered from double infection in Barretos belonged to genotypes I and III, respectively.
\end{abstract}

KEYWORDS: Dengue virus; Dual infection; RT/PCR, E/NS1 gene sequences; Phylogenetic analysis.

\section{INTRODUCTION}

Dengue, one of the most threatening mosquito-borne diseases of humans, is caused by any of the four-serotypes (DEN-1 to 4) of dengue virus, a positive-strand RNA virus. Two clinical forms of dengue infection have been recognized: dengue fever, a relatively mild, self limiting febrile illness and dengue hemorrhagic fever/dengue shock-syndrome (DHF/ DSS), a severe infection with vascular and haemostatic abnormalities that can lead to death ${ }^{3}$.

In Brazil, infection by dengue virus has increased significantly in the last two decades, after the reintroduction of mosquito vector Aedes aegypti. Epidemiological surveillance remains the only way to prevent dengue outbreaks since an effective vaccine is not available.

DEN-1 was introduced in São Paulo State in 1987 and since 1990 successive dengue fever epidemics have been occurring. DEN-2 was introduced in $1996^{24}$. In 2000, DEN-3 was detected for the first time in Brazil, in this state, resulting from an imported case ${ }^{25}$. Autochthonous cases of infection caused by this serotype were registered in Rio de Janeiro State on summer of $2001^{19}$ and since then the virus has spread into others states of Brazil, co-circulating with DEN-1 and DEN-2 in many geographic areas increasing the risk of more severe illness.

Barretos, a city with about 105,000 inhabitants in the North Region of São Paulo State, underwent a great dengue outbreak by DEN-1 and
DEN-2 in the year of 2001 with 3,045 laboratory and clinically confirmed cases (Centro de Vigilância Epidemiológica da Secretaria de Estado da Saúde de São Paulo). This work reports the isolation and molecular characterization of dengue viruses detected in a case of naturally acquired double viral infection during this epidemic. The patient presented classic dengue fever and was fully recovered from the illness.

\section{MATERIALS AND METHODS}

Viral isolation and serotype identification: The patient, a 15-year old boy living in Barretos, presented febrile illness compatible with dengue fever. Blood sample was collected on the first day after the onset of the symptoms and sent to Instituto Adolfo Lutz. The presence of dengue virus was investigated by inoculation of $20 \mu \mathrm{l}$ serum aliquot/ tube to Aedes albopictus clone C6/36 cells culture and the isolated virus was typed by indirect fluorescent antibody test using serotype-specific monoclonal antibodies according to GUBLER et al., 1984 ${ }^{4}$. The two isolated viruses were registered in our file respectively as SPH 194757d1 and SPH 194757d2 strains.

\section{Molecular characterization}

RT-PCR: Viral RNA was isolated from the culture supernatant of the first passage to $\mathrm{C} 6 / 36$ infected cells according to the procedure described elsewhere ${ }^{1}$. Reverse-transcription and amplification were conducted in a single reaction tube by the procedure described by

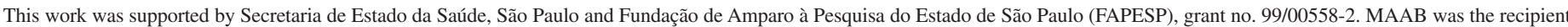
of a fellowship from FAPESP.

(1) Serviço de Virologia, Instituto Adolfo Lutz, Av. Dr. Arnaldo 355, 01246-902 São Paulo, SP, Brasil.

(2) Departamento de Epidemiologia, Faculdade de Saúde Pública, Universidade de São Paulo, Av. Dr. Arnaldo 715, São Paulo, SP, Brasil.

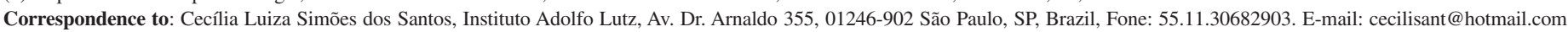




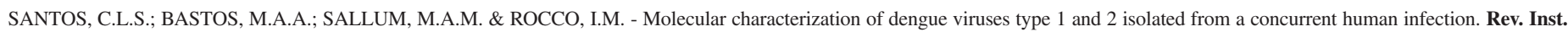
Med. trop. S. Paulo, 45(1):11-16, 2003.

LANCIOTTI et al. ${ }^{14}$. Second-round amplification with type specific primers resulted in different DNA bands, characteristic for each dengue virus type that could be observed directly in agarose gel stained with ethidium bromide.

Sequencing of the E/NS1 gene junction: A region encompassing 240 nucleotides of the envelope/non structural (E/NS1) gene junction was amplified by RT-PCR with primers described by RICO-HESSE ${ }^{21}$. Nucleotide sequencing reactions were performed directly from the PCR products by using the "ABI Prism ${ }^{\mathrm{R}}$ Big Dye ${ }^{\mathrm{M}}$ Terminator Cycle Sequencing Ready Reaction Kit” (PE Applied Biosystems, Foster City, CA, USA). Approximately $10 \mathrm{ng}$ of purified DNA, for each sequencing reaction, was combined with $3.2 \mathrm{pmol}$ of primer (sense and/or reverse) used in the amplification reaction. Nucleic acid sequence analysis was performed on an automated Applied Biosystems 377 DNA sequencer.

Nucleotide and amino acid sequences alignment: Nucleic acid sequences of the E/NS1 gene junction of strains SPH 194757d1(AF520798 Genbank accession number) and SPH 194757d2 (AF520799 Genbank accession number) were aligned with the corresponding reference viruses, Nauru strain ${ }^{16}$ for DEN-1 and PR159S1 strain $^{6}$ for DEN-2 by using the multiple sequence alignment method implemented in CLUSTAL $X^{28}$. The MEGA software ${ }^{10}$ was used in the final documentation. Base sequences of E/NS1 gene junction of DEN-1 and DEN-2 viruses used in the present phylogenetic study were described elsewhere ${ }^{21}$.

Phylogenetic analysis: Maximum likelihood (ML) phylogenetic analysis was performed using PAUP $4.0 \mathrm{~b} 10^{27}$. The computer program Modeltest version $3.06^{20}$ was used to choose an appropriate model of sequence evolution and model parameter values. Under the adopted model and using a $\mathrm{NJ}$ tree as the starting tree for branch-swapping, five iterative rounds of ML analysis were performed, using the less intensive (NNI) to those using more intensive (TBR) branch-swapping. The most likely tree identified during each of these rounds was used as the starting tree for the next search, both for calculation of updated parameter values and for the initiation of branch-swapping. Branch-swapping were respectively, Nearest Neighbor Interchange (NNI), Subtree Pruning Regrafting (SPR), and SPR, Tree Bisection-Reconnection (TBR) and TBR. Bootstrapping ${ }^{2}$ under the ML criterion utilized 100 pseudoreplicates with a single random-taxonaddition starting tree per pseudoreplicate and TBR branch-swapping. Model parameter values were set to the optimal values estimated during the likelihood search procedure described above.

\section{RESULTS}

The infected C6/36 cell culture showed a clear-cut cytopathic effect when observed on light microscope. The indirect fluorescent tests with the serotype-specific monoclonal antibodies were positive for DEN-1 and DEN-2 viruses, the latter serotype showing a more intense fluorescent reaction.

Analysis by RT-PCR confirmed the double infection. Agarose gel electrophoresis of the nested PCR products showed two bands, corresponding to positive controls of DEN-1 and DEN-2 viruses (Fig. 1). A more intense ethidium-bromide fluorescent band of DEN-2 in comparison with that of DEN-1 suggests a higher viral load of DEN-2 in the patient, in agreement with the immunological assay.

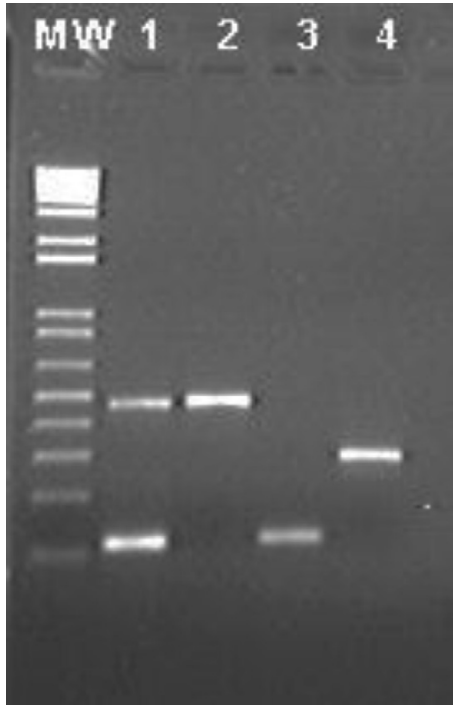

Fig. 1 - RT PCR product analysis by electrophoresis $1.5 \%$ agarose gel from RNA extracted from the patient with dual infection (Lane 1). Positive controls of dengue viruses 1 to 3 are shown in lanes 2 to 4 , respectively, and molecular markers (MW) are on the left.

Molecular characterization of the strains SPH 194757d1 and SPH 194757 d 2 was performed by sequencing a 240 -nucleotide region from the E/NS1 gene junction, classically employed in phylogenetic studies ${ }^{21,22}$. The nucleotide alignments of the sequences of these isolates with the corresponding reference virus strains are shown in Fig. 2A and 3A, respectively. From these analyses we are able to detect some nucleotide changes, mainly occurring in the third codon position. The inferred amino acids encoded by the E/NS1 gene junction region of strain SPH 194757d2 differed at few sites when compared to the reference virus PR159S1 (Fig. 3B), while the nucleotide substitutions observed in the strain SPH 194757 d 1 resulted only in silent mutations when compared to the Nauru reference strain (Fig. 2B).

The E/NS1 gene alignment for DEN-1 consisted of 240 positions, of which 71 were variable and 40 were parsimony informative. For DEN2 , the alignment was also 240 positions, of which 85 were variable and 73 were parsimony informative. Hierarchical likelihood ratio test and AIC, both implemented in Modeltest $3.06^{20}$, found that the models that best fit the DEN-1 data for E/NS1 gene were TrNef + G and SYM + I + $\mathrm{G}$, respectively, and for DEN-2 were $\mathrm{TrN}+\mathrm{G}$ and GTR $+\mathrm{G}$, respectively. ML analyses were conducted under SYM + I + G for DEN-1 and GTR $+\mathrm{G}$ for DEN-2 datasets. Likelihood analysis for the E/NS1 dataset of DEN-1 virus performed under SYM + I + G model generated two similar ML topologies both with $-\operatorname{lnL}=1121.34445$. In both ML trees, BRASPD1 is placed within the clade formed by genotypic group I. One of ML trees is shown in Fig. 4A. Placement of BRASPD1 within Group I clade is in agreement with DEN-1 virus classification proposed by RICO-HESSE ${ }^{21}$. ML bootstrap support for this clade is weak $(<50 \%$ bootstrap proportion). Results of ML analyses of DEN-2 for E/NS1 using the GTR + G model generated two ML trees both with $-\operatorname{lnL}=$ 1304.52350. In both ML topologies, BRSPD2 strain groups with genotypic group III of RICO-HESSE ${ }^{21}$. One of these two ML trees is shown in Fig. 4B. ML bootstrap support for the genotypic group III clade is weak $(<50 \%$ bootstrap proportion). 
A

\begin{tabular}{|c|c|}
\hline & 2282 \\
\hline Nauru & AUAGGGAUUCUGCUGACAUGGCUAGGAUUAAACUCAAGGAGCACGUCCCUUUCAA UGACG \\
\hline BRASPD1 & 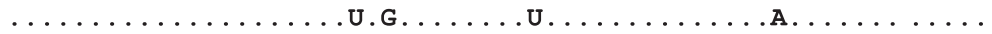 \\
\hline Nauru & UGUAUCGCAGUUGGCAUGGUCACACUGUACCUAGGAGUCAUGGUUCAGGCGGACU CGGGA \\
\hline BRASPD1 & 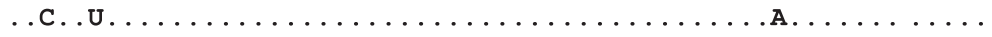 \\
\hline Nauru & UGUGUAAUCAACUGGAAAGGCAGAGAACUCAAAUGUGGAAGCGGCAUUUUUGUCA CCAAU \\
\hline BRASPD1 & 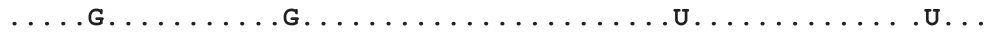 \\
\hline & \\
\hline Nauru & GAAGUCCACACCUGGACAGAGCAAUAUAAAUUCCAGGCCGACUCCCCUAAGAGAC UAUC \\
\hline BRASPD1 & 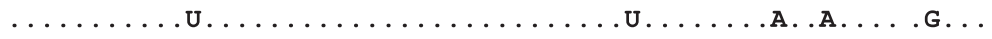 \\
\hline
\end{tabular}

B

$739 \quad 818$

Nauru IGILLTWLGLNSRSTSLSMTCIAVGMVTLYLGVMVQADSGCVINWKGRELKCGSG IFVTNEVHTWTEQYKFQADSPKRLS

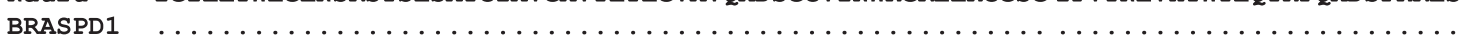

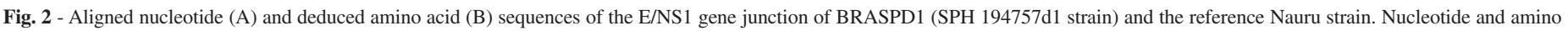
acid positions are numbered according to MASON et al $^{16}$. Dashes indicate identities.

A

\begin{tabular}{|c|c|}
\hline \multicolumn{2}{|r|}{2311} \\
\hline PR159S1 & AUAGGAGUUAUCAUCACAUGGAUAGGAAUGAACUCACGUAGCACAUCACUGUCU GUGUCA \\
\hline BRASPD2 & 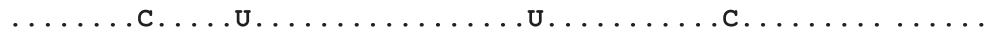 \\
\hline PR159S1 & CUGGUAUUAGUGGGAAUCGUGACACUGUACUUGGGAGUUAUGGUGCAGGCCGAU AGUGGU \\
\hline BRASPD2 & $\ldots$ A. . . . . . . . . . . . . . . . . . . . . . . . . \\
\hline PR159S1 & UGCGUUGUGAGCUGGAAGAACAAAGAACUAAAAUGUGGCAGUGGAAUAUUCGUC ACAGAU \\
\hline BRASPD2 & $\ldots \ldots \ldots$. . . . . U.G. . . . . . . . A.U . . \\
\hline & 2550 \\
\hline PR159S1 & AACGUGCAUACAUGGACAGAACAAUACAAGUUCCAACCAGAAUCCCCUUCAAAA CUGGCU \\
\hline BRASPD2 & 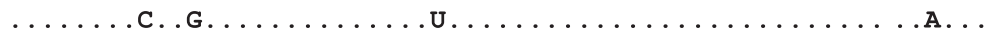 \\
\hline
\end{tabular}

$\mathbf{B}$

$\begin{array}{ll}739 & 818\end{array}$

PR159S1 IGVIITWIGMNSRSTSLSVSLVLVGIVTLYLGVMVQADSGCVVSWKNKELKCGSG IFVTDNVHTWTEQYKFQPESPSKLA

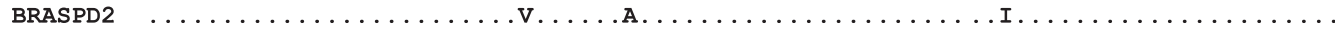

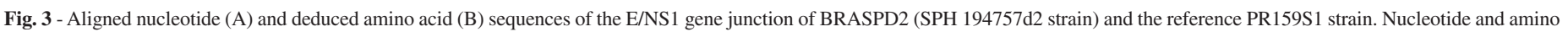
acid positions are numbered according to HAHN et $a l^{6}$. Dashes indicate identities.

\section{DISCUSSION}

A case of dual viremia in a patient with classic dengue fever is reported in this work. The viruses were isolated in C6/36 mosquito cells culture and identified as dengue virus of serotypes DEN-1 and DEN-2 by indirect immunofluorescent assay and RT-PCR. Molecular characterization was performed by sequence analysis of E/NS1 gene junction region, comparing these isolates with other geographically and temporally distinct DEN-1 and DEN-2 viruses ${ }^{21}$. Phylogenetic analysis indicated that DEN-1 and DEN-2 viruses isolated from the dual infection fall into the genotypes I and III respectively, within RICO-HESSE's dengue 1 and 2 virus classification ${ }^{21}$.

Several techniques, such as ribonuclease T1 oligonucleotide fingerprinting ${ }^{30}$, restriction enzyme analysis ${ }^{31}$, and nucleotide sequence determination of different genomic fragments ${ }^{15,18,21}$, have been used to detect dengue virus variation among serotypes. These techniques showed that dengue viruses could be grouped into clusters called topotypes, 


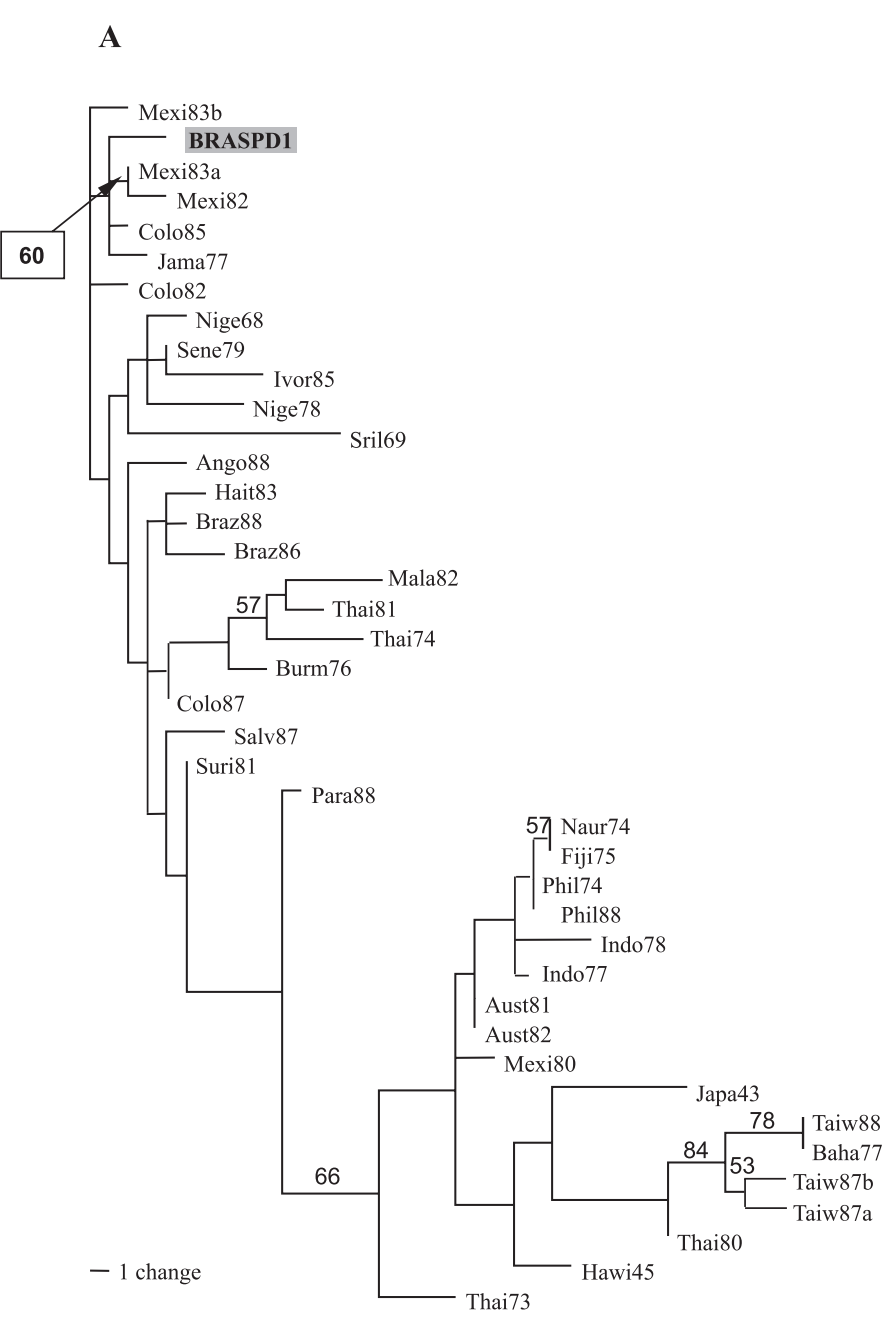

\section{B}

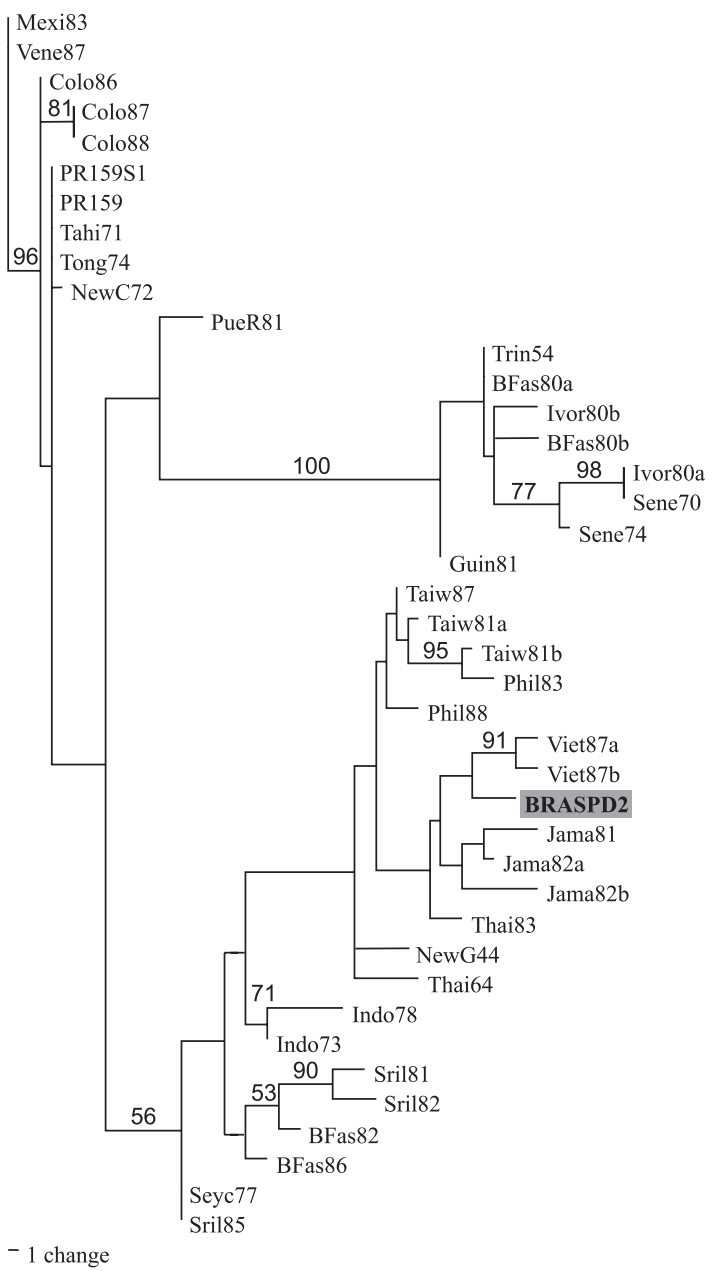

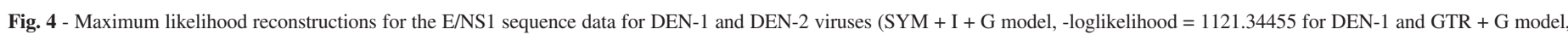

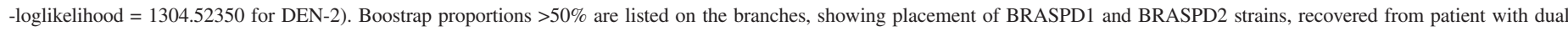
infection in Barretos, State of São Paulo, Brazil. (A) DEN-1 virus. (B) DEN-2 virus.

genotypes, or subtypes. In Brazilian samples of dengue viruses, the genetic analysis based on Hae III endonuclease restriction mapping identified topotypes Caribbean and Jamaica for DEN-1 and DEN-2 viruses, respectively ${ }^{31}$. When partial sequencing of gene $\mathrm{E}$ fragment was used to study strains of DEN-2 isolated in the states of Rio de Janeiro, Ceará, Bahia and Alagoas during the 1990-1995 dengue outbreaks, the subtype III was detected ${ }^{18}$ in agreement with results showed earlier by LEWIS et al. ${ }^{15}$ that used the entire E gene in the phylogenetic studies of a DEN-2 strain isolated in Rio de Janeiro in 1990. The subtype III corresponds to Jamaica topotype and is closely related to genotype III described by RICO-HESSE ${ }^{21,22}$.

The comparison of E/NS1 nucleotide sequences between DEN-1 and DEN-2 viruses recovered from the dual infection in the year of 2001 and DEN-1 and DEN-2 Brazilian strains isolated in 1986,1988,1990 21,22 revealed differences, but these are not enough to propose a new genotype when a value of $6 \%$ divergence was taken as the cutoff point for virus relationships ${ }^{21}$.
Considered as a whole, these results may indicate that only one genotype for DEN-1 and for DEN-2 have been circulating in Brazil, since the reintroduction of the disease.

Natural concurrent infection with dengue viruses may occur in highly endemic areas where different dengue serotypes have been transmitted for many years. Many cases of simultaneous infection by more than one arbovirus species in mosquito or human hosts have been documented elsewhere ${ }^{5,9,12,13,17,26}$, and our laboratory has already reported one case of dengue 1 and 2 co-infection in a patient with mild infection ${ }^{23}$.

Simultaneous infection by different strains of dengue viruses in human or mosquito host cells affords the potential for virus recombination. In this regard, recent evidence provided by phylogenetic and rigorous nucleotides sequence analyses of dengue virus genomes showed that recombination is an important, yet largely ignored, mechanism responsible for generation of dengue virus diversity ${ }^{7,29,32}$. Therefore, the genetic exchange between dengue strains, although rarely 
reported in positive-strand RNA viruse ${ }^{11}$ might be, in addition to mutation, important factor involved in genetic variation of dengue virus ${ }^{8}$.

Due to the complexity of dengue infection and the difficulties in obtaining a safe and effective vaccine, recombination and its role in the genetic diversity of dengue virus must be investigated further. Strains isolated from cases of natural concurrent infection could be good models in such studies.

\section{RESUMO}

\section{Caracterização molecular de vírus Dengue tipo 1 e 2 isolados de um paciente com dupla infecção}

A cidade de Barretos, com cerca de 105.000 habitantes e situada na região norte do Estado de São Paulo, apresentou, no ano de 2001, importante epidemia de dengue causada por vírus dengue de sorotipos 1 e 2. Nesta epidemia foi detectado um caso de dupla infecção viral em um paciente acometido pela forma clássica da doença. Os vírus foram isolados em cultura de células C6/36 e identificados como vírus dengue 1 e 2 por reações de imunofluorescência e RT-PCR. A análise molecular por sequienciamento de nucleotídeos da junção dos genes E/NS1 dos vírus em estudo mostrou a presença de regiões bem conservadas quando comparados aos vírus protótipos, observando-se algumas alterações nucleotídicas que em sua maioria originaram mutações silenciosas. Resultados da análise de verossimilhança máxima para a inferência filogenética das seqüências E/NS1 indicaram que os vírus dengue 1 e 2 isolados do paciente pertencem aos genótipos I e III respectivamente.

\section{ACKNOWLEDGMENTS}

The authors thank to Dr Maria Luisa Barbosa for helpful discussions and Dr Tiyo Sakurai for the critical reading of the manuscript.

\section{REFERENCES}

1. CHOMCZYNSKI, P. \& SACCHI, N. - Single step method of RNA isolation by acid guanidinium thiocyanate-phenol-chloroform extraction. Analyt. Biochem., 162: 156$159,1987$.

2. FELSESTEIN, J. - Confidence limits on phylogenies: an approach using the bootstrap. Evolution, 39: 783-791, 1985.

3. GUBLER, D.J. - Dengue and dengue hemorrhagic fever. Clin. Microbiol. Rev., 11: 480-496, 1998.

4. GUBLER, D.J.; KUNO, G.; SATHER, G.E.; VELEZ, M. \& OLIVER, A. - Mosquito cell cultures and specific monoclonal antibodies in surveillance for dengue viruses. Amer. J. trop. Med. Hyg., 33: 158-165, 1984.

5. GUBLER, D. J.; KUNO, G.; SATHER, G.E. \& WATERMAN, S.H. - A case of natural concurrent human infection with two dengue viruses. Amer. J. trop. Med. Hyg., 34: 170-173, 1985.

6. HAHN, Y.S.; GALLER, R.; HUNKAPILLER, T. et al. - Nucleotide sequence of dengue 2 RNA and comparison of the encoded proteins with those of other flaviviruses. Virology, 162: 167-180, 1988.

7. HOLMES, E.C.; WOROBEY, M. \& RAMBAUT, A. - Phylogenetic evidence for recombination in dengue virus. Molec. Biol. Evol., 16: 406-409, 1999.
8. HOLMES, E. C. \& BURCH, S.S. - The causes and consequences of genetic variation in dengue virus. Trends Microbiol., 8: 74-77, 2000.

9. KANESA-THASAN, N.; IACONO-CONNORS, L.; MAGILL, A. et al. - Dengue serotypes 2 and 3 in US forces in Somalia. Lancet, 343: 678, 1994.

10. KUMAR, S. \& TAMURA, M. - MEGA: molecular evolutionary genetics analysis, Pennsylvania. The Pennsylvania State University Park, PA, 1993, version 1.06.

11. LAI, M.M.C. - RNA recombination in animal and plant viruses. Microbiol. Rev., 56: 61-79, 1992.

12. LAILlE, M.; DEUBEL, V. \& SAINTE-MARIE, F.F. - Demonstration of concurrent dengue 1 and dengue 3 infection in six patients by polymerase chain reaction. $\mathbf{J}$. med. Virol., 34: 51-54, 1991

13. LAM, K.S.K. \& MARSCHALL, I.D. - Dual infection of Aedes aegypti with arboviruses. I. Arboviruses that have no apparent cytopathic effect in the mosquito. Amer. J. trop. Med. Hyg., 17: 625-636, 1968.

14. LANCIOTTI, R.S.; CALISHER, C.H.; GUBLER, D.J.; CHANG, G.J. \& VORNDAM V. - Rapid detection and typing of dengue viruses from clinical samples by using reverse transcriptase-polymerase chain reaction. J. clin. Microbiol., 30: 545-551, 1992.

15. LEWIS, J.A.; CHANG, G.-J.; LANCIOTTI, R.S. et al. - Phylogenetic relationships of dengue-2 viruses. Virology, 197: 216-224, 1993.

16. MASON, P.W.; McADA, P.C.; MASON, T.L. \& FOURNIER, M.J. - Sequence of the dengue-1 virus genome in the region encoding the three structural proteins and the major nonstructural protein NS1. Virology, 161: 262-267, 1987.

17. MEYERS, R.M. \& CAREY, D.E. - Concurrent isolation from patient of two arboviruses, chikungunya and dengue type 2. Science, 157: 1307-1308, 1967.

18. MIAGOSTOVICH, M.P.; NOGUEIRA, R.M.R.; SCHATZMAYR, H.G. \& LANCIOTTI, R.S. - Molecular epidemiology of DEN-2 virus in Brazil. Mem. Inst. Oswaldo Cruz, 93: 625-626, 1998.

19. NOGUEIRA, R.M.R.; MIAGOSTOVICH, M.P.; FILIPPIS, A.M.B.; PEREIRA, M.A.S \& SCHATZMAYR, H.G. - Dengue virus type 3 in Rio de Janeiro, Brazil. Mem. Inst. Oswaldo Cruz, 96: 925-926, 2001.

20. POSADA, D. \& CRANDALL, K.A. - MODELTEST: testing the model of DNA substitution. Bioinformatics, 14: 817-818, 1998.

21. RICO-HESSE, R. - Molecular evolution and distribution of dengue viruses type 1 and 2 in nature. Virology, 174: 479-493, 1990.

22. RICO-HESSE, R.; HARRISON, L.M.; SALAS, R.A. et al. - Origins of dengue type 2 viruses associated with increased pathogenicity in the Américas. Virology, 230: 244$251,1997$.

23. ROCCO, I.M.; BARBOSA, M.L. \& KANOMATA, E.H.N. - Simultaneous infection with dengue 1 and 2 in a Brazilian patient. Rev. Inst. Med. trop. S. Paulo, 40: 151154, 1998.

24. ROCCO, I.M.; FERREIRA I.B.; KATZ, G. et al. - Ocorrência de dengue no Estado de São Paulo, Brasil, de 1986-1996. Rev. Inst. Adolfo Lutz, 57: 7-12, 1998.

25. ROCCO, I.M.; KAVAKAMA, B.B. \& SANTOS, C.L.S. - First isolation of dengue 3 in Brazil from an imported case. Rev. Inst. Med. trop. S. Paulo, 43: 55-57, 2001.

26. SISOUK, T.; KANEMURA, K. \& SAITO, M. - Virological study on dengue epidemics in Vientiane municipality, Lao PDR. Jap. J. trop. Med. Hyg., 23: 121-125, 1995.

27. SWOFFORD, D. L. - PAUP and other methods. Phylogenetic analysis using parsimony. Sunderland. Sinauer Associates, 2002. version 4.0 b10. 
SANTOS, C.L.S.; BASTOS, M.A.A.; SALLUM, M.A.M. \& ROCCO, I.M. - Molecular characterization of dengue viruses type 1 and 2 isolated from a concurrent human infection. Rev. Inst. Med. trop. S. Paulo, 45(1):11-16, 2003.

28. THOMPSON, J.D.; GIBSON, T.J.; PLEWNIAK, F.; JEANMOUGIN, F. \& HIGGINS, D.G. - The CLUSTAL $X$ windows interface: flexible strategies for multiple sequence alignment aided by quality tools. Nucleic Acids Res., 24: 4876-4882, 1997.

29. TOLOU, H.J.; COUISSINIER-PARIS, P.; DURAND, J.P. et al. - Evidence for recombination in natural populations of dengue virus type 1 based on the analysis of complete genome sequences. J. gen. Virol., 82: 1283-1290, 2001.

30. TRENT, D.W.; MANSKE, C.L.; FOX, G.E. et al. - The molecular epidemiology of dengue viruses: genetic variation and microevolution. Appl. Virol. Res., 2: 293-315, 1990.
31. VORNDAM, V.; NOGUEIRA, R.M.R. \& TRENT, D.W. - Restriction enzyme analysis of American region dengue viruses. Arch. Virol., 136: 191-196, 1994.

32. WOROBEY, M.; RAMBAUT, A. \& HOLMES, E.C. - Widespread intra-sorotype recombination in natural populations of dengue virus. Proc. nat. Acad. Sci. (Wash.), 96: $7352-7357,1999$

Received: 4 June 2002

Accepted: 7 November 2002 